\title{
Lawsuits against plastic surgeons: Does locale affect incidence of claims?
}

\author{
Jonathan L Kaplan MD MPH, Warren C Hammert MD DDS, James E Zin MD
}

\begin{abstract}
JL Kaplan, WC Hammert, JE Zin. Lawsuits against plastic surgeons: Does locale affect incidence of claims? Can J Plast Surg 2007;15(3):155-157.
\end{abstract}

BACKGROUND: Physicians continue to practice in a very litigious environment. Some physicians try to mitigate their exposure to lawsuits by avoiding geographical locations known for their high incidence of medical malpractice claims. Not only are certain areas of the United States known to have a higher incidence of litigation, but it is also assumed that certain areas of the hospital incur a greater liability. There seems to be a medicolegal dogma suggesting a higher percentage of malpractice claims coming from patients seen in the emergency room (ER), as well as higher settlements for ER claims. OBJECTIVE: To determine if there is any validity to the dogma that a higher percentage of malpractice claims arise from the ER.

METHODS: An analysis of common plastic surgery consults that result in malpractice claims was performed. The location where the basis for the lawsuit arose - the ER, office (clinic) or the operating room $(\mathrm{OR})$ - was evaluated. The value of the indemnity paid and whether its value increased or decreased based on the location of the misadventure was evaluated.

RESULTS: According to the data, which represented $60 \%$ of American physicians, there was a larger absolute number of malpractice claims arising from the OR, not the ER. However, the highest average indemnity was paid for cases involving amputations when the misadventure originated in the ER.

CONCLUSIONS: The dogma that a greater percentage of lawsuits come from incidents arising in the ER is not supported. However, depending on the patient's injury and diagnosis, a lawsuit from the ER can be more costly than one from the OR.

Key Words: Emergency room lawsuits; Malpractice claims

Dhysicians continue to practice in a very litigious environ1 ment and despite attempts to reduce susceptibility to lawsuits, there is still a malpractice crisis (1). Physicians may try to mitigate their exposure to lawsuits with several techniques. They can change their practice behaviour or attempt to avoid certain high-risk situations altogether. An additional technique, possibly the most important in reducing claims, is communication with the patient even in the midst of a complication $(2,3)$.

Two recent articles $(4,5)$ demonstrate behavioural changes that attempt to minimize the risk of litigation. In an effort to reduce lawsuits related to informed consent, physicians can alter their practice behaviour by obtaining informed consent in the office and documenting the discussion. This was suggested

\section{Les poursuites contre les plasticiens : Le lieu influe-t-il sur l'incidence des actions?}

\begin{abstract}
HISTORIQUE : Les médecins continuent d'exercer dans un milieu très litigieux. Certains médecins tentent de limiter leur exposition aux poursuites en évitant les régions géographiques connues pour leur forte incidence d'actions en négligence professionnelle médicale. Certaines régions des États-Unis sont non seulement reconnues pour leur plus forte incidence de litiges, mais il est également postulé que certains départements des hôpitaux sont davantage soumis aux poursuites. Il semble exister un dogme médicolégal laissant supposer un plus fort pourcentage d'actions en négligence professionnelle de la part de patients ayant consulté à l'urgence, ainsi qu'un plus grand nombre de règlements amiables reliés à l'urgence.
\end{abstract}

OBJECTIF : Déterminer si le dogme selon lequel un plus fort pourcentage d'actions en négligence professionnelle proviennent de l'urgence est valable.

MÉTHODOLOGIE : On a procédé à une analyse des consultations courantes en chirurgie plastique qui entraînent des actions en négligence professionnelle. On a évalué le lieu où s'était produit l'incident (l'urgence, le bureau ou la clinique ou la salle d'opération). On a également évalué la valeur de l'indemnité versée et son augmentation ou sa diminution selon le lieu de l'incident.

RÉSULTATS : D'après les données, qui représentaient $60 \%$ des médecins états-uniens, le nombre absolu d'actions en négligence professionnelle provenait davantage de la salle d'opération que de l'urgence. Cependant, les indemnités moyennes les plus élevées étaient versées par suite d'actions relatives à des amputations, et l'incident s'était produit à l'urgence.

CONCLUSIONS : Le dogme selon lequel un plus fort pourcentage de poursuites découle d'incidents ayant eu lieu à l'urgence n'est pas vérifié. Cependant, d'après la blessure et le diagnostic du patient, une poursuite découlant d'un incident s'étant produit à l'urgence peut coûter plus cher que s'il s'est produit à la salle d'opération. 


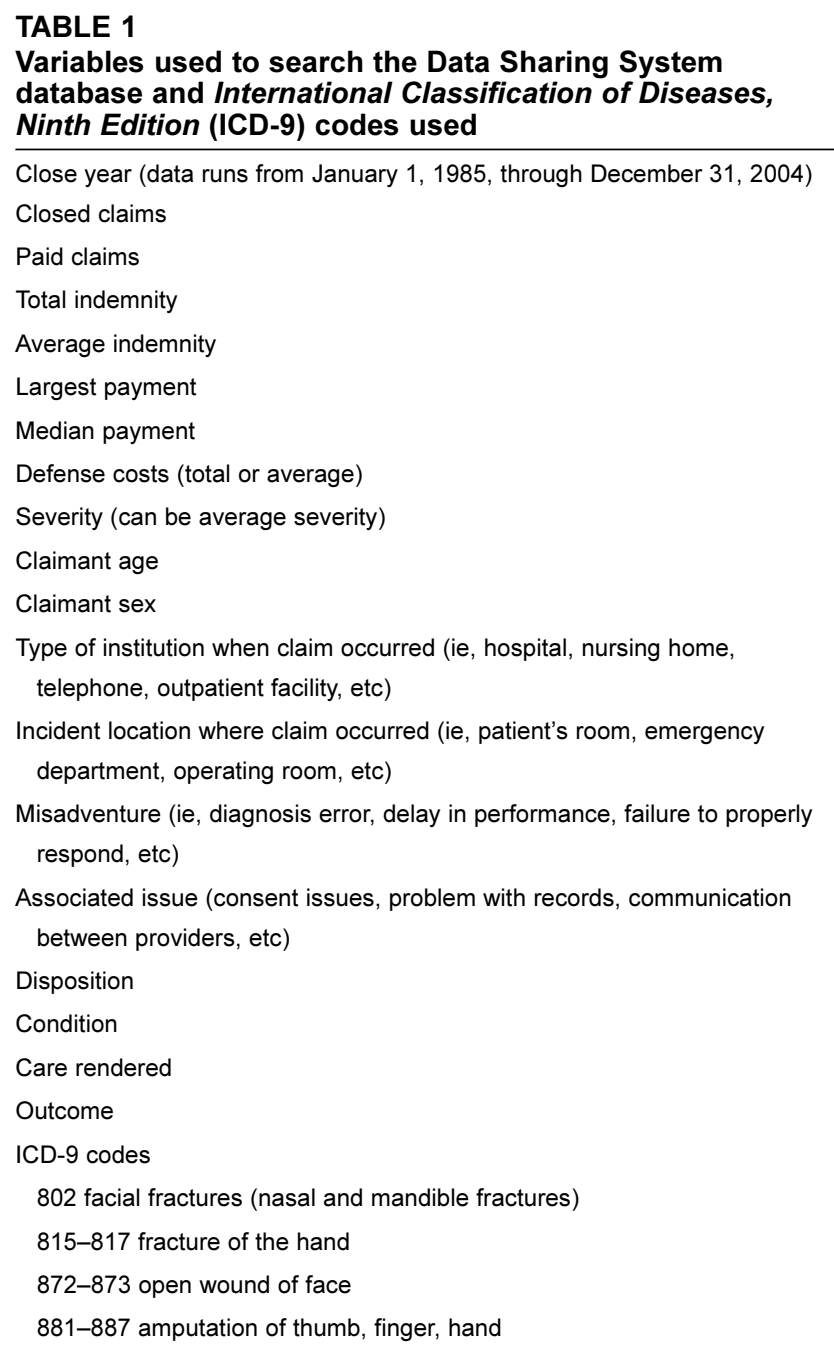

an analysis of malpractice claims involving plastic surgeons in the ER, office and operating room (OR). Claims were crossreferenced to the International Classification of Diseases, Ninth Revision (ICD-9) codes that represent typical plastic surgery consults from the ER. We hypothesized that when compared with the office or OR, the majority of the misadventures leading to lawsuits would come from incidents that occurred in the ER and the resulting claims would incur a higher payment to the plaintiff.

\section{METHOD}

Data were extracted from the Physician Insurers Association of America (PIAA) database. PIAA represents 40 member companies that insure over $60 \%$ of the United States' doctors. Its international membership provides indemnification to more than 775,000 health care providers around the world. PIAA representation includes more than 20 major medical and dental specialties. The PIAA operates the Data Sharing System the database used for the present study - which consists of over 200,000 cases reported by PIAA members between January 1, 1985, and June 30, 2005 (8).

Table 1 lists the fields used to search the database and determine what information was needed for the study. In particular, the ICD-9 codes that relate to common plastic surgery consults from the ER, including facial injuries and hand injuries, were cross-referenced to the location where the misadventure originated.

Because the database uses legal rather than medical terms, the definitions of terms will be reviewed for clarity. Misadventures, for the purpose of the present study, are accidents caused by a health care professional. Examples of misadventures specific to the ICD-9 codes examined include surgical foreign body retained, improper performance, medication error, wrong patient or wrong body part, failure to instruct or communicate with patient, and no medical misadventure.

Closed claims are those lawsuits in which a disposition has been reached - they were settled before litigation, dismissed, filed but not prosecuted, judged without trial, given a directed verdict or overturned upon appeal. Claims that resulted in a payment to the plaintiff, the amount paid and the indemnity are listed under paid claims in Table 2.

\section{RESULTS}

The diagnoses and procedures were compared within the context of where they originated (Table 2). Amputations of thumbs, fingers or hands (ICD-9 codes 881 to 887 ) had a greater number of closed claims in the OR $(n=66)$ than the ER $(n=50)$. A higher absolute number of paid claims as well as a higher percentage of paid claims were received by plaintiffs from the OR $(n=15,22.7 \%)$ than the ER $(n=9,18 \%)$. However, the claims paid to plaintiffs from the ER were more costly, with an average indemnity of US\$165,666.67 versus US\$63,330.87 to plaintiffs from the OR.

A greater number of closed claims from nasal fractures (ICD-9 code 802) came from OR patients than ER patients (36 claims versus one). The same pattern occured for mandible fractures (ICD-9 code 802), with 50 claims from OR patients and 12 from ER patients. The average indemnity was significantly higher for nasal and mandible fractures when the misadventure occurred in the OR (US\$42,749.88 and US $\$ 46,894.00$ versus US $\$ 6000$ and US $\$ 25,666.00$, respectively).

Claims resulting from diagnosis of open wounds of the face, which included scalp and ear injuries (ICD-9 codes 872 and 873 ), were more common from the OR, but the absolute numbers of cases were small (four versus two). There was one paid claim from each location, each for an indemnity of US $\$ 25,000$.

For diagnoses involving fractures of the hand or fingers (ICD-9 codes 815 to 817 ), there were more closed claims originating from the OR (25) than the ER (10). Five claims were paid to OR patients whereas two claims were paid to ER patients. The average indemnity was US\$27,699.80 for OR misadventures and US $\$ 17,500.00$ for ER misadventures.

\section{DISCUSSION}

The number of claims in all categories was smaller in the ER than the OR. This is most likely due to the greater number of patient encounters in the OR and the office than the number of patient encounters in the ER. This is appropriate because one would expect more claims from the area of the hospital where the surgeon has a larger number of patients.

For diagnoses involving amputations of the finger, thumb or hand (ICD-9 codes 881 to 887 ), there is a seemingly disproportionate number of claims from the ER (50) compared with the OR (66). We were unable to determine the total number 
TABLE 2

Claims made for the following International Classification of Diseases, Ninth Revision (ICD-9) codes from January 1, 1985, through June 30, 2005

\begin{tabular}{|c|c|c|c|c|c|c|}
\hline ICD-9 & $\begin{array}{c}\text { Type of } \\
\text { institution }\end{array}$ & Incident location & $\begin{array}{l}\text { Closed } \\
\text { claims, } n\end{array}$ & $\begin{array}{c}\text { Paid } \\
\text { claims, } n\end{array}$ & $\begin{array}{c}\text { Average indemnity, } \\
\text { US\$ }\end{array}$ & $\begin{array}{c}\text { Total Indemnity, } \\
\text { US\$ }\end{array}$ \\
\hline \multirow[t]{3}{*}{$881-887$} & Hospital & Operating room & 66 & 15 & $63,330.87$ & $949,963.00$ \\
\hline & Hospital & Emergency department & 50 & 9 & $165,666.67$ & $1,491,000.00$ \\
\hline & Practitioner's office & Not in inpatient facility & 24 & 5 & $41,900.00$ & $209,500.00$ \\
\hline $802.0,802.1$ & Hospital & Operating room & 36 & 8 & $42,749.88$ & $341,999.00$ \\
\hline (nasal) & Hospital & Emergency department & 1 & 1 & $6,000.00$ & $6,000.00$ \\
\hline $802.2,802.3$ & Hospital & Operating room & 50 & 21 & $46,894.00$ & $984,774.00$ \\
\hline (mandible) & Hospital & Emergency department & 12 & 3 & $25,666.00$ & $77,000.00$ \\
\hline \multirow[t]{3}{*}{$872-873$} & Hospital & Operating room & 4 & 1 & $25,000.00$ & $25,000.00$ \\
\hline & Hospital & Emergency department & 2 & 1 & $25,000.00$ & $25,000.00$ \\
\hline & Practitioner's office & Other & 1 & 0 & - & - \\
\hline \multirow[t]{4}{*}{$815-817$} & Hospital & Operating room & 25 & 5 & $27,699.80$ & $138,499.00$ \\
\hline & Practitioner's office & Not in inpatient facility & 12 & 4 & $9,812.50$ & $39,250.00$ \\
\hline & Hospital & Emergency department & 10 & 2 & $17,500.00$ & $35,000.00$ \\
\hline & Hospital & Patient's room & 2 & 0 & - & - \\
\hline
\end{tabular}

881-887 amputation of thumb, finger, hand; 802 facial fractures, nasal or mandible; 872-873 open wound, face; 815-817 fracture of hand

of ER consults for amputations over the past 20 years, which would provide a denominator for calculating the proportion of claims to consults. This also limited the present study such that we were unable to determine the relative risk of litigation involving a patient from the ER.

An additional interesting find involved the diagnosis of amputations in the ER. The average indemnity paid to ER patients was approximately US $\$ 100,000$ more than if the misadventure had occurred in the OR or in the office.

The dogma that ER consults tend to be more litigious cannot be supported or denied based on our findings. There may be a suggestion that a disproportionate share of ER patients file malpractice cases for amputations of the finger, thumb and hand, but without knowledge of the total number of consults for this diagnosis, this dogma cannot be substantiated.

However, our data do support the notion that lawsuits from the ER can be substantially more expensive than if the misadventure occurred in the $\mathrm{OR}$.

\section{CONCLUSION}

Our findings indicate there may be increased litigation involving patients with traumatic hand injuries, particularly amputations. Due to the more costly nature of paid claims from the ER for hand injuries, medical malpractice carriers may charge higher premiums for those treating these conditions. However, this extra expense should not be the responsibility of the surgeon providing a service to the hospital and community. The hand surgeon should be compensated for the extra expense, either through direct financial payments from the hospital or indirectly via malpractice insurance premium assistance.

\section{REFERENCES}

1. Mello MM, Studdert DM, Brennan TA. The new medical malpractice crisis. N Engl J Med 2003;348:2281-4. (Erratum in 2003;349:1010)

2. Aly A, Gorney M. Essentials of malpractice claims prevention for the plastic surgeon. <www.emedicine.com/plastic/topic431.htm> (Version current at July 16, 2007).

3. Levinson W, Roter DL, Mullooly JP, Dull VT, Frankel RM. Physician-patient communication. The relationship with malpractice claims among primary care physicians and surgeons. JAMA 1997;277:553-9.

4. Bhattacharyya T, Yeon H, Harris MB. The medical-legal aspects of informed consent in orthopaedic surgery. J Bone Joint Surg Am 2005;87:2395-400.

5. Bhattacharyya T, Vrahas MS. The medical-legal aspects of compartment syndrome. J Bone Joint Surg Am 2004;86-A:864-8.

6. Mello MM, Kelly CN. Effects of a professional liability crisis on residents' practice decisions. Obstet Gynecol 2005;105:1287-95.

7. Halpern D. Should plastic surgeons be obligated to take ER call? Plastic Surgery News. February 2006;14.

8. Physicians Insurers Association of America. Introduction to PIAA Data Sharing System. Rockville, Maryland, 2005. 